\title{
THE AFRICAN WORLDVIEW AS THE BASIS OF PRACTICE IN THE HELPING PROFESSIONS
}

\section{Dumisani Thabede}

\section{INTRODUCTION}

This paper endeavours to point out some of the specific elements that constitute the African worldview that both educators and practitioners in the helping professions should be aware of when providing social casework/counselling services to African people. Social workers need to be sensitive to the African worldview when dealing with African clients, because this worldview informs the way in which Africans relate to phenomena, including challenges that life presents to African clients. In this paper the following aspects will be addressed: the meaning of the African worldview; the existence of thee African worldviews; the rationale for embracing the African worldview; the unity/common elements of the African worldview/culture; and the elements of the African worldview that caseworkers have to consider (beliefs and practices) such as belief in God, belief in ancestors, belief in witchcraft and traditional healing, polygamy, rites of passage.

Reve (1995:1) states that "...the word African has been debatable due to the fact that many people also claim to be Africans. This has created real confusion as to what an African is". African in this context refers to African (Black) people who are residents of South Africa and fall within the Zulu, Xhosa, Sotho, Tsonga and Venda ethnic groups. Furthermore, African in this context excludes the White, Coloured and Indian populations residing in South Africa. The exclusion of White, Coloured and Indian from the African worldview is based on the understanding that these racial groups have their own unique and distinct worldviews which deserve a separate in-depth enquiry. In the social sciences the African, Coloured and Indian worldviews are relatively marginalised as the basis of professional interventions in the helping professions. The marginalisation of the African worldview may be the reason why most Africans adhere simultaneously to both traditional/African and Western psychological treatment regimes when they contend with psychopathological challenges.

\section{DEFINITION OF KEY CONCEPTS}

\section{Afrocentrism}

In the context of this paper the terms African worldview, Afrocentric worldview and African thought are regarded as synonymous. The development of the term "Afrocentricity" must be attributed to Asante (1987). He introduced the concept in 1980 in his book titled "Afrocentricity: the theory of social change" (Gray, 2001:19). Asante (1987:6) defines Afrocentricity as meaning literally placing African culture at the centre of any analysis that involves studying African people. Afrocentricity is a perspective that allows Africans to be subjects of historical experiences rather than objects on the fringes of Europe. This implies that Afrocentrists are concerned with discovering the centred place of the African in every case (Asante, 1999:111).

The term Afrocentric, according to Gray (2001:3), refers to "an idea and a perspective which holds that African people can and should see, study, interpret and interact with people, life, and reality from the vantage point of African people rather than from the vantage point of European people, or Asian, or other non-African people, or from the vantage point of African people who 
are alienated from Africanness". This means that Africans should view phenomena from the vantage point of an African worldview which is in turn informed by African culture.

Hill (in Mekada, 1999:110) states that "Afrocentric or African centred are interchangeable terms referring to the quality of thought and practice which is rooted in the cultural image and interest of African people and reflects the life experiences, history and traditions of African people as the center of analyses ... the terms African-centred worldview or Afrocentric worldview have been used to describe the cultural values of people of African origin and African descent throughout the world".

\section{AFRICAN WORLDVIEW}

Barker (1999:522) defines worldview as the way a person tends to understand his or her relationship with social institutions, nature, objects, other people and spirituality. The Africancentred or Afrocentric worldview is, according to Asante (1987), one that is based on African cultural beliefs, practices and values. Barker (1999:114) defines culture as the customs, habits, skills, arts, values, ideology and religious behaviour of a group of people. Graham and AlKrenawi (2003:9-10) define culture as "the totality of ideas, beliefs, values, knowledge, and a way of life of a group of people who share a certain historical, religious, racial, linguistic, ethnic or social background". African culture refers to the customs, beliefs, values, knowledge habits, skills, arts, values and a way of life of African people. An African worldview is the worldview that is informed by African culture (Barker, 1999; Graham \& Al-Krenawi, 2003).

\section{AFROCENTRIC PERSPECTIVE}

The above definitions and descriptions suggest that the Afrocentric perspective entails the need:

- for the helping professions and the related social sciences in South Africa to create space for the subjugated, marginalised African culture-based epistemologies, such as the African culture-based theories/ideas of clinical intervention;

- for the helping professions in South Africa to acknowledge the significance of African culture in providing social services to the African people;

- to accept that phenomena can be viewed from the point of view of the Africans themselves. Afrocentrism affirms the validity of the African worldview and epistemology as an alternative perspective to understanding phenomena;

- to accommodate the Afrocentric perspectives as a significant part of the knowledge base and practice alongside current Eurocentric intervention theories and practices;

- to predicate the theory and practice of the helping professions in South Africa on African culture, so that the helping professions will reflect the worldview and cultural values of those who mostly are recipients of mental health services in South Africa;

- to acknowledge that African cultural knowledge is important in addressing the psychological, intellectual, spiritual and emotional needs of African people;

- to move away from foreign frameworks and notions used to analyse Africans' psychological, social and psychosocial problems;

- to develop a multicultural curriculum for the helping professions, with an emphasis on African culture. 


\section{THE EXISTENCE OF AN AFRICAN WORLDVIEW}

The idea that the African worldview and the Western thought/worldview exist and are different is supported by several authors, such as Van der Walt (1997), Torrey (1972), Kamalu (1990) and Gyekye (1995). According to Torrey (1972), people do not see things in the same way, and the way they see things is dependent on their cultural beliefs. Ideas, values, conceptions of time and the notion of cause and effect are all culturally learned. The world is differently defined in different places.

The Afrocentric paradigm is a social science paradigm premised on the philosophical concepts of traditional Africa. The origins of the African worldview were found in traditional Africa before the emergence of European influences. Although colonisation and the vilification of Africa by Europeans and Arabs modified Africa to some extent, several writers maintain that the philosophical integrity of traditional Africa has survived among continental Africans. Africa has survived long enough to render Africans a distinct African ethos (Mazrui, 1986; Mbiti, 1990).

It is therefore inappropriate to apply the Eurocentric theories of human behaviour to explain the behaviour of Africans. European theories of human behaviour reflect notions of human behaviour developed in European and Anglo-American cultures; these Eurocentric theories of human behaviour claim to provide universal explanations of human behaviour. Afrocentrists do not believe in social science universalism, namely that one theory or paradigm can be used to explain human behaviour of all people in all cultures. European political, economic and scientific hegemony has unfortunately led to the hegemony of knowledge production and validation, particularly in academia, that marginalises the indigenous worldviews of people of colour (Schiele, 2000).

According to Van der Walt (1997), African thought exists and differs from Western thought in that Western thought generally ignores the spiritual dimension of phenomena and focuses on the visible, measurable physical reality. In Western thought supernatural causes are not considered to be plausible explanations for phenomena. However, in African thought supernatural causes play an important role in explaining phenomena. Africa does not ignore the supernatural side of reality as the West does. African ontology is concerned with the spiritual world and the forces that play a role in it. Africans regard supernatural causes as the explanation for everything. Western thought is mainly intellectual, devoid of emotional content. African thought, on the contrary, is more involved, more personal, emotionally affective and expressive.

Van der Walt (1997:89) says: "In contrast to modern man, whose approach to life is objectively analytical and whose spirit is accordingly also divided into values, thought and feeling systems, Africans have a different approach. They do not face the world objectively and at a distance but live in it. No objects exist outside reality. They touch and are attuned to things and the earth. They experience everything intensely and are part of everything."

To an African, therefore, affective, intuitive, irrational and scientific knowledge are all equally valid. Daniels (2001:303) states that "The African worldview ... acknowledges affective reality as well as rationality". In terms of African thought one is not faced with the options of being rational or irrational; it is possible, rather, for one to relate to phenomena through all the modes or patterns of thought and being. Kamalu (1990:13) states that modern man/woman has in a way been mentally straight-jacketed by rational thinking. Opposed to this pattern of thought is the vitalist mentality of ancient Egyptian science. This involved the use of intuition (feeling or 
emotional sensitivity) in addition to reason, and it led to a more immediate attainment of the truth rather than through a logical step by step progression. The intellect alone could not lead one to a full knowledge of phenomena.

Gyekye (1995:201) alludes to the idea of paranormal cognition as an important mode of knowing in African thought. Western knowledge has acknowledged two main sources of knowledge: reason and sense experience, also known as rationalism and empiricism respectively. Clairvoyance and telepathy, which are forms of extrasensory perception, are not formally accepted as ways of knowing in Western epistemology. An important aspect of African epistemology that differentiates it from Western epistemology is spirit mediumship, divination and witchcraft. These modes of cognition are common in all African communities. It can be legitimately declared that paranormal cognition is recognised by and large as one of the modes of knowing in Africa.

Helping professions need to be aware of African thought patterns, so that they are able to choose appropriate intervention strategies that take into account the scientific, the irrational, the intuitive, the affective and the spiritual modes of knowing and being. Some of these interventions may be outside the purview of the helping professions, which is when helping professionals may need to refer clients appropriately or work jointly with other service providers, such as faith healers, traditional healers and diviners.

\section{THE RATIONALE FOR EMBRACING THE AFRICAN (AFROCENTRIC) WORLDVIEW}

According to Schiele (2000:2), many scholars have argued that the knowledge base of the social sciences and helping professions is characterised by a European-American cultural hegemony that validates the existential experiences, paradigms and theories that have emerged from Western intellectual history and thought. This has created problems, the main problem being the Africans' usually unconscious adoption of the Western worldview, perspective and conceptual framework to the total exclusion of their own view of the world. The challenge is to displace Western ways of thinking, being and feeling, and to replace them with ways that are germane to African cultural experiences.

Swigonski (1996:4) stated that the "Afrocentric perspective shows how developing knowledge of another culture from the perspective of that culture can transform professional practice. Knowledge developed in this way enables the profession to work more profoundly for the empowerment of clients". This means that an Afrocentric perspective starts with the question: "Does this place Africans in the centre? Is it in the best interest of African peoples?" An Afrocentric perspective further describes the ethos and the values of Africans. Afrocentric work reorganises the African frame of reference so that African history, culture and worldview become the context for understanding Africans. Understanding African clients within their context begins to challenge the privileged status of the European worldview and places them in the centre of their conception of reality.

Since the knowledge base of the helping professions is dependent upon Eurocentric social science theory and research, diagnostic and intervention paradigms also suffer from the Eurocentric cultural universalism in which the cultural values of Africans have not been used sufficiently as a theoretical base to formulate new human service practice paradigms and problem-solving methods (Schiele, 2000:5). The Afrocentric perspective on professional practice is confronted with the problem of establishing its own unique order of knowledge based on African culture and premised on the African worldview. This culture-based 
indigenous knowledge will mitigate the problem of relevance that helping professions are facing in a culturally diverse country like South Africa.

\section{The unity of African culture}

There are claims that Africans have diverse cultures, to the extent of denying the existence and the unity of African culture, which is, however, confirmed by Africans. These claims have gone to the extent of identifying Africa south of the Sahara as "Black Africa" and what is north of the Sahara as the Middle East (Asante \& Asante, 1985:4). According to these claims, it is impossible for Africa to have a united culture, since there are too many ethnic groups in Africa. There are further arguments that Africa is too vast, that the peoples and cultures are different, and therefore nobody should make sweeping generalisations. Africa is vast; however, the Arabs of North Africa are not Africans but Asiatics, though they have their residence in a physical or geographic area called Africa. The white people of Zimbabwe or South Africa are not Africans but Europeans. Within each African country there are differences between ethnic groups, and in the final analysis there are differences between all individuals. If knowledge of African culture depends on the study of every African country, each ethnic group, each village, each household and each individual, then that kind of knowledge can never be attained (Ruch \& Anyanwu, 1981:79).

Amazingly, these arguments do not apply to European culture or Asian culture, and are therefore one-sided. When it comes to Europe, irrespective of the various ethnic groups that exist in Europe, European culture remains united, according to them; they refer to it as Western civilisation (Reve, 1995:3). When it comes to African culture, minor differences are used to divide Africans, whilst the same differences in other groups are ignored in favour of unifying factors. A classic example of how African cultures were used to divide Africans occurred when South Africa was sliced up into different homelands based on cultural differences among Africans.

What is most amazing is that there are even Africans who deny cultural unity in Africa. Pobee (in Reve, 1995) claims there is a plethora of "African cultures"; he claims that there is a gulf between Africa north of the Sahara and Africa south of the Sahara, between East Africa and West Africa and that this results in differences in culture between these regions. He further argues that there are differences within Africa and these differences are remarkable even within one country, and they are due to tribal backgrounds. What is most striking is that while Pobee (in Reve, 1995) repeatedly talks of African cultures and religions, he never talks of Christianities. This makes one wonder if he does not see any remarkable differences within Christianity itself. Is his Christianity as an Anglican similar to that of a Methodist? If so, why do we have so many churches; if not, why not Christianities and not Christianity (Reve, 1995:3)?

Empirical researchers into African culture proclaim that the African people have changed, that their traditional beliefs have collapsed and that they have become modern. Ruch and Anyanwu (1981) state that the task here is to investigate what it is that subsists of the ancient beliefs beneath their apparent changes. He asks whether, in spite of the mutation of time, there is anything enduring by which people can be known? And he also mentions that we speak of biological inheritance, but do not mention cultural inheritance. All cultures of the world are dynamic. They change with time, but there are elements within those cultures that have been there, are there and will continue to be there. Daniels (2001:303) states that Afrocentric writers agree that the African community, regardless of divergent life experiences, has retained basic principles of the African value system to some degree, for example, the ideas of the 
interconnectedness of all things; oneness of mind, body and spirit; collective identity as opposed to individual identity; consanguineous family structure; phenomenological time; and spirituality.

Nabwire (1968:25) states that foreign observers have often been misled into thinking that Africans have absorbed European and American cultures with no sense of selectivity. Even with the European acculturation and with a wholesale rejection of African folkways, there remains a continuing strong pulse of African life below the European clothes. Complete imitation of European or American or Chinese culture would be bound to fail, because Africa does not have binoculars viewing New York, London, or Peking to mimic what they do.

Despite efforts of succeeding white governments in South Africa to stress differences between various groups such as the Nguni, Tsonga, Sotho and Venda, there is a sense in which all these peoples have a common culture (Hammond-Tooke, 1993). Arguing that African people share a similar culture does not necessarily mean that there are no diverging experiences among Africans. Indeed there are differences, but they are not as great as the Africans' difference from Europeans or Asians. Some of the differences are due to extraneous cultural influences of nonAfricans (Asante \& Asante, 1985:11).

Ngunis, Sothos, Vendas and Tsongas in South Africa are Africans; though ethnically different, they share common cultural beliefs, such as the belief in ancestors, witchcraft, and polygamy. Gyekye (1995) states that a comparative study of African cultures shows that, despite the undoubted cultural diversity arising from ethnic pluralism in Africa, threads of underlying affinity do run through the beliefs, customs, value systems, socio-political institutions and practices of the various African societies. There is a very widespread corpus of ideas that persists in the rituals, myths and folktales of African peoples. Continental Black Africa reveals common cultural trends among its peoples, such as a belief in a Supreme Being, polygamy and primacy of the collective/community as against that of the individual.

Mekada (1999) also points to a number of cultural values that are common throughout the continent of Africa. The main principles of the African-centred worldview are: the interconnectedness of all things; the spiritual nature of human beings; collective individual identity; the collective/inclusive nature of family structure; the oneness of mind, body and spirit; and the value of interpersonal relationships. This worldview has important implications for social work practice with Africans and all people of African descent.

The following are some of the enduring common themes that characterise African culture: cosmology, belief systems, epistemological systems, rites of passage, forms of marriage, music, dance and the history of colonisation and domination by the European nations. HammondTooke (1972) states that all African societies have some belief in the supernatural being; belief in ancestors; the custom of a bride living at the home of her husband's father; polygamous marriage; prohibitions on mating with close kin; the incest taboo; and a universal sense of dependence on the supernatural being.

It is important for the helping professionals to be aware of the fact that, even though African culture is dynamic, like all other cultures, there are core cultural traits that have endured through time and colonisation. Some Africans may have adopted Christianity, but there are times when they will do things in the African cultural way. They may go to church to worship and also go to the graveyard to speak to the deceased members of their family who have become ancestors. Occasionally one gets the feeling that Africans have a way of dealing in contradictions, incorporating things in their lives that seem to be contradictory, for example, 
taking a particular problem to church, to the ancestors, to the helping professional and to traditional healers at the same time.

The point to be made here is that helping professionals need to be open to what may seem to be contradictory behaviours by African clients. If the client speaks to the helping professional in English, and also mentions prayer and God in the conversation, the helper must not assume that, just because the client is literate and Christian, he or she does not look at things from an African cultural perspective. Underneath or side by side with English, God and the Church, there will always be an enduring cultural core in every African client. The following are some the cultural beliefs that characterise African culture.

\section{Beliefs}

Practitioners who deal with African clients need to know the beliefs that characterise African culture so that they are able to begin where the African client is, psychologically. What African clients believe informs both their behaviour and the rituals they engage in to address life challenges.

\section{Belief in ancestors}

Hammond-Tooke (1974:325) defines ancestors as the spirits of the dead members of the lineage or clan. The Zulus refer to ancestors as amadlozi or amathongo; the Xhosa call ancestors izinyanya, the Tsonga call them swikwembu, the Tswana, Pedi and Sotho call them badimo. It cannot be denied that the departed occupy an important place in African religiosity. The departed, whether parents, brothers, sisters or children, form part of the family and must be kept in touch with their surviving relatives. Africans do not worship their ancestors; they only remember them by performing certain rites and rituals, such as libation and the giving of food to the departed as tokens of fellowship, hospitality and respect.

Throughout Zulu history, the ancestors have been looked upon as the source from which help and guidance can be derived after appropriate rituals and through sacrificial offerings. The ancestral spirits, commonly known as the Amadlozi, Amakhosi or Amathonga, are of fundamental importance to the Zulu. They are the departed souls of the deceased. Though they are regarded as having gone to abide in the earth, they continue to have a relationship with those still living in the village. They are regarded as positive, constructive and creative presences. They are also capable of meting out punishment when they have been wronged or ignored. Veneration is their due, failure to show proper respect to them invites misfortune and proper veneration ensures benefit. The ancestors therefore are powers for good or ill (Earhart, 1993:38-39).

The Xhosa refer to ancestors as izinyanya whereas the Mpondo call them amathongo. All old people who die become ancestral spirits and can influence the lives of their descendants, communicating with them through dreams and omens. A woman can be an ancestral spirit to her children and her sons' children. Ancestors continue to influence a woman after marriage and a married woman is thought to be influenced by the ancestors of her husband as well (Magubane, 1998).

The Basotho believe that the ancestors play an important role in curing a wide variety of diseases and ailments. Their assistance is invoked through divination by a ngaka (doctor) (Magubane, 1998). The Tsonga believe that every human being becomes an ancestor (shikwembu), but the fate of the children dying in infancy is one for which there is no very clear explanation (Hammond-Tooke, 1974:327). 
Western missionaries, anthropologists, journalists and scholars who criticise ancestor worship should look at or consider cemeteries in their home countries and see how many flowers, candles and even photographs of the dead are put on the graves of relatives and friends. That is often more extreme than anything found in Africa and the researcher does not know what to call this form "worship" in the West. African peoples do not feel ashamed to remember the departed members of their family. Remembering them is not worshipping them (Mbiti, 1990:9).

The Tsonga believe in a Supreme Being to whom the creation of man and the earth is attributed. They believe that man has a physical body (mmiri) and a spiritual body. The spirit enters the body at birth and on death is released to join the ancestors. Ancestor worship is still practised today. It requires the performance of rituals, particularly during crises, under the direction of a nanga (diviner). The family gathers at the gandzelo (a place set aside for rituals and sacrifices) to pay homage to their ancestral spirits. Intercession is made for help with specific problems and during times of crime. Belief in ancestor influence in daily life is common, particularly in sickness (Magubane, 1998).

\section{Belief in the Supreme Being}

Like people everywhere, the Africans ask existential questions about the origins of the earth. How and by whom was the earth created? What is man's place in creation? Is there life after death? Most of all: What are the causes of evil? And how should one cope with misfortunes and exigencies of life? They, too, have their own notions of a Supreme Being who assists them to come to grips with the ultimate questions. Religion provides them with emotional support in times of distress, and explanatory theories about the origin of nature and the fate of the cosmos and human life (Hammond-Tooke, 1974:318).

Religions of Africa, Mesoamerica and the native religions of North America have sometimes been called "primitive religions". Some authors have argued convincingly against this categorisation. The religions of Africans, Mesoamericans and Native North Americans should be considered together with all other religions. They, as other religions, constitute a distinctive set of beliefs, symbols, rituals, practices and doctrines that enable members of these groups to establish and maintain a meaningful world (Earhart, 1993:7).

African knowledge of God is expressed in proverbs, idioms, short statements, songs, prayers, names, myths, stories and religious ceremonies. All these are easy to remember and pass on from one generation to another. Since there are no sacred writings as in other traditional societies, one should not expect to find long dissertations about the Supreme Being. God is no stranger to African people; in traditional life there are no atheists. This is captured in the Ashanti proverb: "No one shows a child the Supreme Being". That means that everyone knows God's existence almost by intuition, and even children know God (Mbiti, 1990:29). Among the Akan people of Ghana there is a similar proverb which says: 'No man needs to teach a child the knowledge of God'. These proverbs indicate that God is so self-evident to an African that no formal religious instruction is necessary. Every tribe in pre-colonial Africa had knowledge of God and spiritual beings (Mbiti, 1990).

All African tribes had and still have an indigenous name for the Supreme Being. The indigenous names of the Supreme Being among the African tribes in South Africa are as follows: the Xhosa - Dali or Qamatha onyawo zilengela eweni; the Zulu - Nkulunkulu or Umvelinqangi (the first to emerge); the Venda - Raluvhimba; and the Sotho, Modimo (Hammond-Tooke, 1974:319). Elsewhere in Africa God is called "the Watcher of everything"; 
"the Great Eye"; "He who bends down ... even the majesties"; and "He who roars so that all nations are struck with terror" (Mbiti, 1990:31).

In addition to the respect they show their ancestors, the Zulu also believe in a supernatural being, uNkulunkulu, who created all wild animals, cattle and game, snakes and birds, water and mountains, as well as the sun and the moon (Magubane, 1998:62). Earhart (1993:39) states that the Zulu have a religious relationship with the sky as well as the earth, the abode of ancestors. The god of the sky is male, father, the earth is female, mother.

There seems to be a connection between the creator god and the ancestral spirits; there is some evidence that the Sotho believe that Modimo can be approached through the medium of the ancestors. The Tsonga attribute the creation of the world to "Nature" (Ntumbuluko), they speak of an impersonal power called Tilo. The Venda deity Raluvhimba is also thought to be vaguely connected with the creation. Among the Sotho Modimo was sometimes seen to manifest himself as lightning or as a thunderbolt and among the Pedi Modimo is closely associated with the elements of nature, wind, rain, hail and lightning. (Hammond-Tooke, 1974:318-320). All African tribes, ethnic groups and cultures thus believe in God and have various names that they use to refer to him.

It is important to note here that all the ethnic groups in this exposé have some enduring myths about the Supreme Being, the origins of the cosmos, tribal and human life. It is important to note that all the ethnic groups within the African culture believed in the supernatural being long before some of them became Christians. This belief forms an integral part of their worldview. The author is also aware of the fact some Africans have adopted the Christian faith by and large without forsaking their indigenous notions of the Supreme Being and belief in ancestors. Helping professionals have to be familiar with the traditional religious beliefs of African clients, so that they are able to respond to the existential and spiritual aspects of the problems clients may be experiencing.

\section{Belief in witchcraft}

Witches or sorcerers are persons who use their power and the forces of nature to harm other people. Anthropologists reserve the term "witch" for someone who harms others by means of a psychic force. This may be unconscious, as among the Venda and the Tsonga, or explicitly conscious, as among the Lobedu, Nguni and Sotho. Witchcraft is believed to be inherited. The Tsonga and the Venda believe that the witch is not aware of her power and is perfectly normal during the day, but at night her spirit leaves her sleeping body and goes out naked to harm her victims. Beliefs in witchcraft are generally similar in most South African Black societies (Hammond-Tooke, 1974:337).

The witch is an unknown individual, almost always considered to be a woman who misuses valid and good power for invalid and evil ends (Earhart, 1993:37-38). It is important to note that both Hammond-Tooke (1974) and Earhart (1993) allude to the fact that women are usually associated with witchcraft. In the Limpopo Province (South Africa) there have been a number of instances in certain villages where aged women were burnt to death because they were suspected of practising witchcraft.

It is important for social workers to acknowledge belief in witchcraft when dealing with African clients. Some clients strongly believe that they have problems because someone is bewitching them. As witchcraft is not logical and scientific, social workers who do not share the client's cultural beliefs might find it a challenge to discuss a client's problems involving witchcraft. It is also important for social workers to realise that attributing problems to 
witchcraft may occasionally be used to hide the client's personal character weaknesses. In African societies, deaths, divorces, accidents, and psychological/psychiatric problems do not just happen, they are often attributed to witchcraft. However, whether witchcraft is real or a figment of the client's imagination, the point here is that witchcraft is an issue that plays a significant role in the lives of Africans. For African clients to tell a social worker that they believe in witchcraft may need very strong client-worker relationships. The client must really feel that his or her secrets are safe with the social worker. The point to be made here is that most Africans believe in witchcraft and that this belief is an important dimension of the African worldview.

\section{Belief in traditional healing}

A traditional healer in other indigenous South African languages is: gqira (Xhosa), inyanga (Zulu), nanga (Tshivenda). Other concepts like: isangoma, izanusi and abalozi (Zulu) and sedupe Northern Sotho refer to specialist categories of traditional healers. Some traditional healers known as dingaka tsa malopo in Northern Sotho community are believed to go into a trance-like state known as malopo. During this altered state of consciousness, a traditional healer is believed to be in contact with the ancestors. A trance-like state known as intlombe and almost similar to the malopo is also observed among the Xhosa people. To add to this long list of names, several English concepts like herbalist, diviner, medicine man, and even derogatory terms like witchdoctor, are used when reference is made to these practitioners of traditional healing (Sodi, 1998).

Gumede (1990), Korber (1990), Kottler (1988) and Schweitzer (1980) generally classify South African traditional healers into four categories, namely diagnosticians, healing doctors, specialists and faith healers. Diagnosticians known as isangoma in (Zulu) have a duty to diagnose the problem, the diviner is charged with the responsibility of determining the cause of the sickness that may from time to time threaten the individuals, families and communities. For example, a diviner may be consulted to find out why cows are barren, fields are not producing crops, the young bride is not having a baby after two years of married life, why there is a misfortune in one's family - in fact why anything has gone wrong (Gumede, 1990) The healing doctors mainly practise the art of therapy or healing. Specialists specialise in specific areas such as stopping lightning and providing protective medicines to bar the activities of evil doers (Gumede, 1990).

\section{RITES OF PASSAGE}

Initiation rites have many symbolic meanings. Through the rites of passage rituals, the youth are introduced to the art of living. The rites of passage are performed when initiates withdraw from other people to live in seclusion in the forest or in specifically prepared traditional huts away from the villages (Hammond-Tooke, 1974; Mbiti, 1990).

The initiation ceremony for the Xhosa marks the end of boyhood and ushers in the beginning of manhood/adulthood (Hammond-Tooke, 1974; Magubane, 1998). Initiation schools for the Venda taught initiates about what to expect and how to behave. Venda girls attend three major initiation schools: vhusha at puberty, tshikanda to reinforce the vhusha, and dombani, a premarital school. In the past no Venda man would marry a woman who had not been through dombani. Among the Zulus the attainment of physical maturity or puberty is called the ukuthomba, which applied equally to boys and girls of the same age and was marked by a period of seclusion during which instructors taught them the requirements and duties of adulthood). Amongst the Basotho, before missionaries introduced schools, education took place 
during initiation, which marked the passage into adulthood. In Ndebele society initiation is still practised among males and females, to mark the passage from childhood to adult status (Magubane, 1998).

In Western cultures the process of reaching adulthood is different and is characterised by different stages, as put forth by different theorists such as Freud, Erikson and Piaget (in Craig, 1983). McPhatter (1997:6) asserts that most social scientists, who were introduced to the mainstream developmental theories of Freud, Erikson and Kohlberg in human behaviour courses, completed this education exchange without knowing that these conceptualisations of normal life-course development describe women and culturally different people as deficient and abnormal. Theorists who describe normal adult development as career attainment, monogamous heterosexual marriage, childbearing and managing a household exclude the developmental experiences of a substantial number of people. In this educational scenario alternative theoretical perspectives are unfortunately either not available or are seldom presented in a positive light.

Craig (1983) explains that Freud lived in the Victorian era. In a number of ways his theory was a reaction to the Victorian notions of human nature and can therefore not be viewed as universally applicable to the understanding of human nature. According to Freud, personality develops through successive psychosexual stages. The stages are as follows: the oral stage, in which the mouth becomes the centre of sensual stimulation and pleasure; the anal and the phallic stages where the focus of pleasure moves from the mouth to the genital area. The genital stage focuses more on sexual and social activities directed towards others.

Sanville (2000:420) states that Freud himself was indifferent to that which existed outside the Western intellectual and artistic traditions. Non-Western cultures were seen as at the neurotic end of the pathological, their shamans as outright psychotic. Freud's followers were intent on developing and defending what they believed to be the universality of their findings and many of the early writers were intent on intellectually colonising the non-Western cultures. They drew upon Freud's theories as if they were proven scientifically. In the opinion of the researcher, Freud raises issues with regards to his theory of human development that are not consistent with African cultures. It is unheard of in African cultures that boys and girls experience sexual feelings for their parents at some stage in their development, as Freud suggests in the Oedipal and Electra complexes.

Westen (1996) explains that Eriksson's theory of human development sees the development of an individual as several stages that encompass all the ages of human life. These are: basic trust versus mistrust; autonomy versus shame and doubt; initiative versus guilt; industry versus inferiority; identity versus identity confusion; intimacy versus isolation; generativity versus stagnation; integrity versus despair. Erikson's theory is not the only model of human development, but it is unique in the sense that it is culture sensitive, emerging not only from Erikson's experience as a psychoanalyst, but also from his having lived among and observed several cultures, from Denmark and Germany to a Sioux reservation (Westen, 1996). Sanville (2000:425) states that developmental constants such as Erikson's might be found in different cultures, but their order and sequence are not as fixed as Erikson suggests, and they vary in length and intensity from culture to culture.

It is important to note here that, though Erikson may have lived with different cultural groups, African culture is not mentioned as one the cultures to which he had been exposed. Therefore his theory of human development can only attempt to explain the development of people whom 
Erikson observed and had lived with. Considering the different paths that people from different cultural backgrounds take towards adulthood, it becomes clear that people who may be regarded as adolescents in some Eurocentric cultures, may be considered fully-fledged adults in some African cultures. What social workers have to realise is that the notion of human development is closely linked to people's cultural background. Part of the education and training of social workers has to include an experience of deliberate cultural immersion in the various cultural settings where they might eventually hope to practise after graduation. This will help to improve their ability to provide social work services cross-culturally.

\section{CONCLUSION}

The literature reviewed in this paper indicates that the African-centred worldview, which the helping professions should understand as the basis of their intervention with African clients, consists of the following enduring and core cultural issue: openness to rational, irrational and spiritual categories of knowledge and being; belief in a Supreme Being which predates the arrival of Christianity; belief in the ancestors; belief in the spiritual nature of a person; belief in witchcraft, and culturally defined rites of passage. Although this paper focuses on the need to incorporate African culture into the training and practice of social casework, there is a parallel challenge to engage in further research studies that will investigate how the worldviews of other population groups in South Africa can be aspects of the worldviews that inform the training and practice of social work in South Africa.

\section{REFERENCES}

ASANTE, M. \& ASANTE, K. 1985. African culture. Westport: Greenwood Press.

ASANTE, M. 1987. The afrocentric idea. Philadelphia: Temple University Press.

ASANTE, M. 1999. The painful demise of eurocentrism. Trenton, NJ: Africa World Press.

BARKER, R.L. 1999. The Social Work Dictionary. Washington, DC: NASW Press.

CRAIG, G. 1983. Human development. New Jersey: Prentice Hall.

DANIELS, J.E. 2001. Africentric social work practice. International Social Work, 44:301309.

EARHART, B. 1993. The religious traditions of the world. San Francisco: Harper.

GRAHAM, J. \& AL-KRENAWI, A. 2003. Multicultural social work in Canada. Canada: Oxford University Press.

GRAY, C.C. 2001. Afrocentric thought and praxis: an intellectual history. Trenton, NJ: Africa World Press, Inc.

GUMEDE, M.V. 1990. Traditional healers: a medical doctor's perspective. Johannesburg: Skotaville Publishers.

GYEKYE, K. 1995. African philosophical thought: the Akan conceptual scheme. Philadelphia: Temple University Press.

HAMMOND-TOOKE, W.D. 1972. The structuring of chaos: anthropological approaches to the human mind. Johannesburg: Witwatersrand University Press.

HAMMOND-TOOKE, W.D. 1974. The Bantu-speaking peoples of Southern Africa. London: Routledge and Kegan Paul. 
HAMMOND-TOOKE, W.D. 1993. The roots of Black South Africa. Johannesburg: Jonathan Publishers.

KAMALU, C. 1990. Foundations of African thought. London: Karnak House.

KORBER, I. 1990. Indigenous healers in a future mental health system: a case for cooperation. Psychology in Society, 14:47-62.

KOTTLER, A. 1988. Professionalization of African healers. Apparent problems and constraints. Psychology in Society, 11:2-17.

MAGUBANE, P. 1998. Vanishing cultures of South Africa. Cape Town: Struik Publishers.

MAZRUI, A. 1986. The Africans: a triple heritage. London: BBC Publications.

MBITI, J.S. 1990. African religions and philosophy. Johannesburg: Heinemann.

McPHATTER, A.R. 1997. Cultural competence in child welfare: what is it? How do we achieve it? What happens without it? Child Welfare, 76:255-278.

MEKADA, J.G. 1999. The African-centered worldview: toward a paradigm for social work. Journal of Black Studies, 30(2):53-59.

NABWIRE, C. 1968. The transferability of North American social work to Black Africa. Milton Obote Foundation.

REVE, N. 1995. The legitimacy of Jesus: an Afrocentric reading of the birth of Jesus. Cape Town: Department of Religious Studies, University of Cape Town. (MA Thesis)

RUCH, E.A. \& ANYANWU, K.C. 1981. African philosophy, an introduction to the main philosophical trends in contemporary Africa. Rome: Catholic Book Agency.

SANVILLE, J.B. 2000. Intracultural and intercultural dialogue in psychoanalytic psychotherapy and psychoanalysis. Clinical Social Work Journal, 28:417-429.

SCHIELE, J.H. 2000. Human services and the Afrocentric paradigm. New York: The Haworth Press.

SWIGONSKI, M.E. 1996. Challenging privilege through Africentric social work practice. Social Work, 41(2):153-162.

SCHWEITZER, R.D. 1980. Indigenous therapy in Southern Africa. Bulletin of the British Psychological Society, 33:278-281.

SODI, T. 1998. A phenomenological study of healing in a North Sotho community. Cape Town: University of Cape Town. (PhD thesis)

TORREY, E.F. 1972. Witchdoctors and psychiatrists: the common roots of psychotherapy and its future. New Jersey: Jason Aronson.

VAN DER WALT, B.J. 1997. Afrocentric or Eurocentric? Our task in a multicultural South Africa. Potchefstroom: Potchefstroom University.

WESTEN, D. 1996. Psychology, mind, brain and culture. New York: John Willey and Sons.

Professor Dumisani Thabede, Senior Lecturer, Department of Social Work, University of Venda, South Africa. 